\title{
First Report of Peronospora dianthicola causing downy mildew of carnation in China
}

\author{
C.F. Duan ${ }^{1}$, A.Z.Tong ${ }^{2}$, Y.Q.Long ${ }^{1}$, G.H.Liu ${ }^{1}$, X.P.Luo ${ }^{1}$, Y.L.Lv ${ }^{1}$, Y.Q.Lou ${ }^{1}$, Z.Y.Zhang ${ }^{2}$, G.H.Yang ${ }^{2}$ and M.Gui $^{3 *}$ \\ ${ }^{1}$ Tropical and Subtropical Cash Crops Research Institute, YAAS, Baoshan, 678025, China; ${ }^{2}$ The Key Lab of Plant Pathology \\ of Yunnan Province, Yunnan Agricultural University, Kunming 650201, China; ${ }^{3}$ The Key Lab of Flower Breeding of Yunnan \\ Province, Flower Research Institute, YAAS, Kunming, 650205, China
}

*E-mail: gming-114@163.com

Received: 13 Jan 2010. Published: 25 Oct 2010. Keywords: Dianthus caryophyllus

Carnation (Dianthus caryophyllus) is the most important cut flower in Yunnan, China. During a survey of carnation plants in Kunming, Yunnan, from 2008 to 2010, pale green leaves that turned yellow with sporulation on both sides of infected leaf surfaces were observed (Fig. 1). Infected plants were stunted and eventually withered. Up to $20 \%$ of carnation plants in the areas surveyed had these symptoms. Microscopic observations showed white conidiophores that turned slightly darker after maturation of conidia. Sporangiophores were 257-388 x 6.9-8.2 $\mu \mathrm{m}$ (average 331 x 7.3 $\mu \mathrm{m})$, ramified dichotomously 3-6 times. Some sporangiophores were observed exiting through the stoma. Sporangia were light brown, obovoid to elliptical, measuring 19.0-22.1 x 16.4-18.6 $\mu \mathrm{m}$ (average $21.0 \times 19.7 \mu \mathrm{m}$ ) with a length/width ratio of 1.0 to 1.3 . Oospores were $39-41 \mu \mathrm{m}$ in diameter, with a yellow-brown, heavily and evenly verrucose or warted wall. Oospores were seen abundantly in leaf sections (Fig. 2). Symptoms on the leaves and oomycete morphology were similar to those described for downy mildew (Francis, 1983). ITS 1 and ITS 4 primers were designed for the amplification of the 5.8s rDNA-ITS region. The amplified ITS sequence of collected sporangiophores and sporangia from infected carnation plants was $873 \mathrm{bp}$. Results of sequence analysis of the isolates showed similarity with sequences from20 isolates of Peronospora spp. in GenBank. The pathogen was identified as belonging to Peronospora dianthicola based onits phenotypiccharacteristics (Francis, 1983).

Pathogenicity tests were performed by inoculating leaves of 60-day-old healthy carnation plants with sporangiophores and sporangia collected

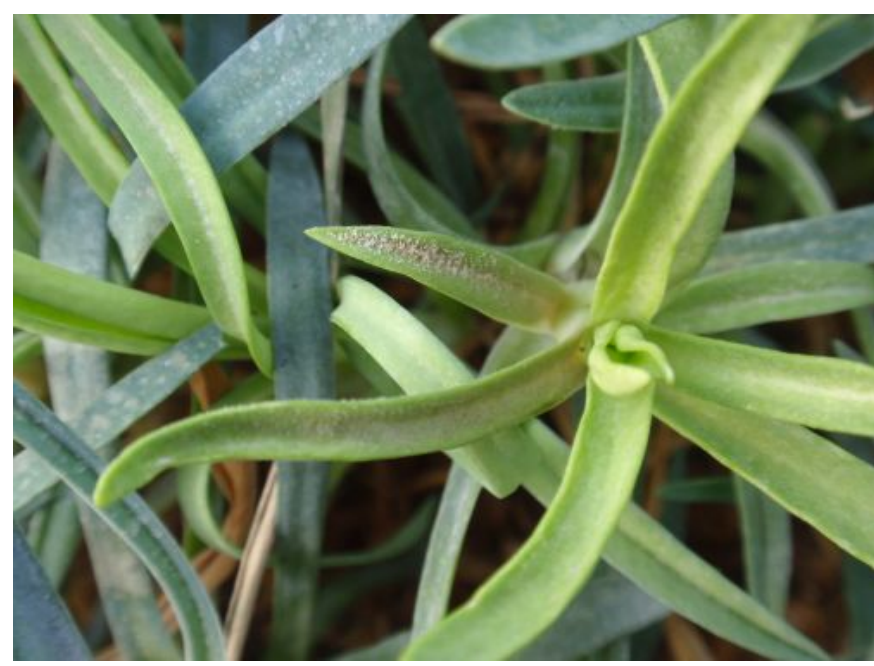

Figure 1 from naturally infected carnation plants. Plants were incubated at $20^{\circ} \mathrm{C}$ and $95 \%$ relative humidity with a $12 \mathrm{~h}$ photoperiod. After 20 days incubation, typical downy mildew symptoms were observed on the inoculated carnation, but no symptoms were observed on water-treated control plants. Downy mildew of carnation caused by $P$. dianthicola has been reported to occur in France (Francis, 1983), Israel (Ben-Ze'ev et al., 2006) and Colombia (Arbeláez, 1979). To our knowledge, this is the first report of downy mildew of carnation caused by $P$. dianthicola in China.

\section{Acknowledgements}

The authors would like to thank the Ministry of Science and Technology of China.

\section{References}

Arbeláez G, 1979. El mildeo velloso Peronospora dianthicola, una neuva enfermedad del clavel en Colombia. Fitopatologia Colombiana 8, 25-26.

Ben-Ze'ev IS, Elkind G, Levy E, 2006. Two Peronospora species causing downy mildew of carnation and gypsophila (Caryophyllaceae) in Israel. Phytoparasitica 34, 265-268. [doi:10.1007/BF02980954]

Francis SM, 1983. Peronospora dianthicola. CMI Descriptions of Pathogenic Fungi and Bacteria No. 764.

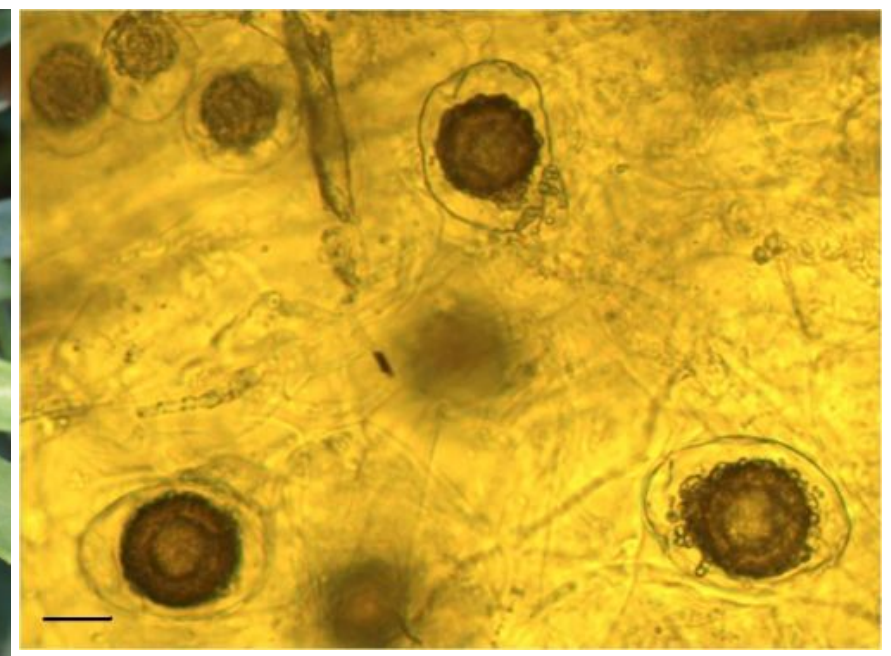

Figure 2

To cite this report: Duan CF, A.Z.Tong, Y.Q.Long, G.H.Liu, X.P.Luo, Y.L.LV, Y.Q.Lou, Z.Y.Zhang, G.H.Yang, M.Gui, 2010. First Report of Peronospora dianthicola causing downy mildew of carnation in China. New Disease Reports 22, 24. [doi:10.5197/j.2044-0588.2010.022.024] (c) 2010 The Authors This report was published on-line at www.ndrs.org uk where high quality versions of the figures can be found. 